\title{
The Intersemiosis of Negative Emotions in the Cinematic Discourse: a Psycholinguistic Perspective
}

\section{Інтерсеміозис негативних емоцій у кінодискурсі: психолінгвістичний ракурс}

\author{
Tetiana Krysanova ${ }^{1}$ \\ Ph.D. in Linguistics, \\ Associate Professor
}

Тетяна Крисанова ${ }^{1}$

кандидат філологічних наук, доцент

E-mail: kobeka72@gmail.com, orcid.org/0000-0002-9456-3845

\section{Iryna Shevchenko ${ }^{2}$}

Dr. in Philology, Professor
Ірина Шевченко ${ }^{2}$

доктор філологічних наук, професор

E-mail: irina.shevchenko7@gmail.com orcid.org/0000-0003-2552-5623

Scopus ID: 57197712617

${ }^{1}$ Lesya Ukrainka Eastern European

National University

13, Volya Avenue, Lutsk, Ukraine, 43025

\section{${ }^{2}$ V.N. Karazin Kharkiv}

National University

$\triangle$ 4, Svobody Sq., Kharkiv, Ukraine, 61022
${ }^{1}$ Східноєвропейський начіональний університет імені Лесі Українки $\triangle$ пр. Волі, 13, м. Луцьк, Україна, 43025

${ }^{2}$ Харківський національний університет імені В.Н. Каразіна $\checkmark$ майдан Свободи, 4, м. Харків, Україна, 61022

Original manuscript received July 04, 2018 Revised manuscript accepted March 11, 2019 


\section{ABSTRACT}

This study of the psycholinguistic properties of negative emotions in the English cinematic feature discourse focuses on the establishment of their intersemiosis the simultaneous multimodal construction of emotional meanings by means of heterogeneous sign systems. The means of meaning construction in the cinematic discourse include linguistic, non-linguistic (prosody, kinesics, etc.) and extra-linguistic (music and kineikonic means), and different modes - acoustic and visual channels for transmitting meanings. The main psycholinguistic properties of cinematic emotions are their inextricable connection with the physiological processes, rootedness in the common human embodied experience, motivational basis; emotions are read as the result of an assessment of the satisfaction degree of individuals' needs. The construction of emotional meanings in the cinematic discourse is the result of the interaction between the real world of the film makers and the imaginary world of the action. In constructing negative emotional meanings in general and emotions of fear and anger, in particular, the collective author of the cinematic discourse uses different semiotic codes in a parity or non-parity way. In the first case, heterogeneous semiotic codes both serve to denote fear or anger, while in the second, advantage is given to one of heterogeneous codes - linguistic, non-linguistic, and extra-linguistic. Consequently, this leads to the domination of one of the modes of transmitting meanings to the collective viewer - acoustic or visual. According to the coherence parameter of the emotional meaning embodied by various means of the semiosis of fear or anger, individual episodes of the English cinematic feature discourse are either congruent or non-congruent. Being congruent, different codes simultaneously transmit the same emotional meaning; being incongruent, heterogeneous semiotic codes actualize different emotional meanings, which leads to higher expressiveness of such emotions and their more effective influence on the viewer.

Key words: intersemiosis, cinematic discourse, emotional meaning making, negative cinematic emotions, semiotic codes, multimodality.

\section{Вступ}

Сфера емоційного в комунікації дедалі частіше досліджується у традиційних і нових ракурсах: з погляду лексикології, синтаксису, семантики, прагматики, теорій образності та символізму, когнітивної лінгвістики, прагматики, психолінгвістики тощо (Ильин, 2001; Мягкова, 2000; Экман, 2010; Argaman, 2010; Carrol, 1999; Frijda, 1986; Gaut, 1999; Saarni, 1993; Tan, 2014). Зокрема, доведено нейробіологічну, психологічну i соціальнокультурну значущість емоцій, встановлено їхню інтенсивність та лінгвальні маркери (Argaman, 2010); однак їх семіозис засобами 
The Intersemiosis of Negative Emotions in the Cinematic Discourse...

гетерогенних кодових систем в кінодискурсі ще чекає на вивчення. Це особливо важливо для негативних емоцій, які переважають у художньому дискурсі (Carrol, 1999). Актуальність такого аналізу зумовлена і непересічною роллю кіно у сучасному світі, i необхідністю встановлення інтерсеміозису емоцій у полікодовому й мультимодальному кінодискурсі.

У психологічних студіях усі запропоновані визначення емоції розглядають іï як складний психологічний стан, «зазвичай пов'язаний 3 порушенням або високим рівнем енергії» (Психологическая энциклопедия, 2006). Поняття «емоція», що етимологічно сходить до психіки людини (від lat. eтоvere - хвилювати), визначають через нейрофізіологічний, нервово-м'язовий і чуттєвий аспекти (Izard, 1991: 69). Емоції пов'язують 3 інстинктами, потребами i мотивами (Леонтьев, 1971: 257); у фільмі - із розвитком контексту i персонажів (Tan, 2018); емоції мають виражене суб'єктивне забарвлення і охоплюють всі види переживань і відчуттів людини (Анохин, 1984: 397).

У сучасних психолінгвістичних дослідженнях, як i в міждисциплінарних лінгвістичних розробках, найбільший інтерес становить зв'язок мови - мислення - людини і світу, зокрема, зв'язок мовної особистості, мовної свідомості і мовленнєвої діяльності (Засєкіна, 2008). Ще Л. Ельмслев відзначав високий евристичний потенціал лінгвістики у тлумаченні світу, вербалізованого людиною, де мова як знакова система слугує ключем до людської думки і до природи людської психіки (Ельмслев, 2006). У кінодискурсі мова поєднана 3 іншими кодами (аудіальним, візуальним) для актуалізації негативних емоцій; вона залежить від психологічної налаштованості глядачів (Tan, 2014). Складність вивчення мультимодального конструювання емотивних значень у полікодових дискурсах пов'язують зі складністю вивчення чуттєвої сфери в цілому, нечіткістю вербалізації іï фрагментів. Розмитість людських емоцій та їх розмаїття образно пояснюється психологами тим, що розум $є$ безпомічним без емоцій, а емоція сліпою без розуму («the reason is helpless without emotion, emotion is blind without the reason») (Strongman, 2003).

Об'єктом нашого дослідження обрано негативні емоції та полікодові засоби їх мультимодальної репрезентації в англомовному кінодискурсі, а предметом - психолінгвістичні характеристики їх 
Інтерсеміозис негативних емоцій у кінодискурсі: психолінгвістичний...

інтерсеміозису в кінодискурсі. Метою дослідження є виявлення психолінгвістичних ознак негативних емоцій, актуалізованих полікодовими засобами в англомовному художньому кінодискурсі. Для цього в роботі вирішуються завдання: в теоретичному плані узагальнити психолінгвістичні й пов'язані з ними соціокультурні параметри дослідження емоцій; у практичному - визначити психолінгвістичні властивості інтерсеміозису негативних емоцій кінодискурсі на прикладі емоції гніву.

\section{Методи дослідження}

За матеріал аналізу у статті слугують епізоди актуалізації емоції страху та гніву 3 американських фильмів «Fracture» i «Titanic». Перший фільм («Тріщина», кінокомпанія Castle Rock Entertainment, 2007, режисер Грегорі Хобліт, сценарій Дениел Пайн, Гленн Джерс, композитори - брати Джефф і Майкл Данна, у головних ролях Ентоні Хопкінс і Райан Гослінг) є трилером (від англ. thrill - хвилювання) - жанр творів літератури / кіно, що має на меті викликати у читача / глядача почуття тривожного очікування, хвилювання, страху. До цього жанру відносять фільми жахів, бойовики, а також пригодницькі, детективні та шпіонські фільми, яким притаманна емоція гніву. У фільмі «Fracture» йдеться про те, як молодий помічник окружного прокурора виявляється втягнутим у хитромудру гру з чоловіком, який намагався вбити свою дружину, але уникнув тюремного ув'язнення завдяки презумпції невинуватості.

Близький за жанром фільм «Тіtanic» (кінокомпанія 20th Century Fox, 1997, режисер і сценарист Джеймс Кемерон, композитор Джеймс Рой Хорнер, у головних ролях Леонардо Ді Капріо та Кейт Вінслет). Це фільм-катастрофа, в якому показано трагічне кохання на фоні загибелі легендарного лайнера.

Страх i гнів належать до фундаментальних емоцій, універсальної базової властивості людини, якій характерне поєднання біологічної та соціальної природи. Біологічна природа страху виявляється у захисній біологічній реакції людини на відчуття реальної або уявної небезпеки для іiі здоров'я та благополуччя (Ильин, 2001). Соціальний характер страху полягає у здатності 
мобілізувати сили людини для активної діяльності, попередити ймовірні помилки і зменшити ризик стати жертвою (Izard, 1991). Тож страх є негативним психічним станом індивіда, що викликаний реальною чи ймовірною малефактивною дією, пов'язаний 3 проявом тривоги, занепокоєння і спрямований на мобілізацію зусиль людини для запобігання спричинення їй шкоди. Гнів $є$ сильним емоційним станом суб'єкта, викликаний малефактивними діями об'єкта, які спричиняють бажання фізичної або моральної відплати об'єкту гніву. Дослідники психологічних аспектів гніву характеризують гнів як конфліктогенну емоцію, що вона має на меті корекцію несправедливості за допомогою певних стандартів поведінки i відрізняється спонтанним характером (Strongman, 2003: 134).

Вивчення інтерсеміозису негативних емоцій, яке ми розуміємо як одночасне мультимодальне конструювання емотивних значень у полікодових дискурсах, потребує залучення низки психологічних критеріїв. Відповідно, для дослідження емоцій страху i гніву в кінодискурсі використовуємо методи спостереження над мовленнєвим матеріалом; семіотичного аналізу для виявлення взаємозв'язку лінгвальних, нелінгвальних i екстралінгвальних елементів, що слугують конструюванню емоції творцями фільму в англомовному кінодискурсі; психолінгвістичний аналіз конструювання смислу емоцій як складного інтенціонально i ситуаційно зумовленого психічного процесу актуалізації негативних емоцій; методики прагмалінгвістичного аналізу дискурсу.

\section{Результати і дискусії}

Лінгвопсихологічні засади дослідження емоцій. Для пояснення полікодового й мультимодального інтерсеміозису емоцій, утворюваних у кінодискурсі, релевантною евристичною базою слугують теорії, що наголошують на лінгвопсихологічних ознаках різних негативних емоцій, зокрема, страху. Серед них фізіологічні, когнітивно-пізнавальні, комунікативні теорії емоцій.

Так, в основі фізіологічних теорій емоиій лежить ідея нерозривного зв'язку емоцій 3 фізіологічними процесами. Згідно периферичної теорії емоцій, тілесне збудження слідує безпосередньо за сприйняттям причини емоції. Подразник викликає 
фізіологічні зміни, які надсилають сигнали в людський мозок, що i провокує виникнення емоції (Джемс, 1991: 308-309). Емоції є результатом усвідомлення вазомоторних і судинно-рухових змін, які відбуваються в організмі людини (Ланге, 2004), причому емоції є одночасними із фізіологічними реакціями на них (Бреслав, 2004). Зокрема, за теорією мімічного зворотнього зв’язку С. Томкінса, певна подія викликає активацію м'язів обличчя, що сприяє, в свою чергу, виникненню емоції (Tomkins, 1980). Мімічний прояв емоцій, на думку П. Екмана (Экман, 2010), культурно опосередкований, хоча й зумовлений універсальними біологічними факторами.

Когнітивно-пізнавальні теорії емоцій виходять із поєднання суб'єктивних емоційних переживань індивіда 3 відображенням об'єктивного змісту, коли процес емоційного переживання відкриває людині смисл відображеного 3 погляду його потреб, слугуючи поштовхом до дії (Вилюнас, 1976).

Емоції пов'язують 3 процесом пізнання, де на перший план виходить поняття оцінки, що є суб'єктивною реакцією на емоційний стимул. Згідно теорії М. Арнольд, оцінка виступає пізнавальною детермінантою емоцій; процес оцінки є інтуїтивним i безпосереднім, несвідомим, миттєвим. Людина спочатку миттєво оцінює ситуацію, а потім несвідомо емоційно реагує на неї (Arnold, 1970). За Р. Лазарусом, кожна емоція є результатом осмислення ситуації і пов'язана з іiі оцінкою (Бреслав, 2004).

Теорія когнітивного дисонансу Л. Фестингера підтверджує тезу про оцінний характер емоцій. Емоції розглядаються як наслідок оцінювання індивідом відповідності / невідповідності між очікуваним і реальним, результатом чого стають позитивні / негативні емоції (Фестингер, 2018).

Тлумачення емоцій у ракурсі соціальної взаємодії знаходить розвиток у трьохкомпонентній моделі ідентифікації емоцій Н. Фріджди, що охоплює суб'єктивне оцінне сприйняття; вербальну або невербальну поведінку; фізіологічні зміни. Згідно цієї теорії, емоції виникають через оцінювання індивідом події як сприятливої або шкідливої для його інтересів; вони є функціональною реакцією індивіда (почуття задоволення / незадоволення) на оточуючі ситуації i подіï, що впливає, в свою чергу, на вибір подальших дій. При цьому емоції викликає не сама ситуація, а значення, яке ій надає індивід (Frijda, 1986). 
The Intersemiosis of Negative Emotions in the Cinematic Discourse...

У конструктивістській теорії емоцій М. Бамберга (Bamberg, 1997) емоції вважаються дискурсивними, а мова - засобом конструювання емоційного смислу, тож вона може бути використана як засіб для вивчення емоцій. Емоції $є$ тими індексами, які вказують на намір мовця і реконструкція смислу емоції слухачем вимагає інференційного умовиводу, тобто розуміння когнітивних, соціальних, культурних аспектів, які супроводжують висловлення. М. Бамберг пропонує когнітивні сценарії емоцій 3 урахуванням ситуативного чинника, в основі якого лежать інтенція, поведінкові характеристики, транзитивність і справедливість дії. Залежно від цих критеріїв виділено когнітивні сценарії, конструкти подій, специфічні для кожної емоції (Bamberg, 1997: 314-317).

Теоретики соціального конструктивізму акцентують залежність емоцій від соціальних правил, що робить їх соціально сконструйованими. Процес конструювання відбувається через культурні норми, власний досвід людини і ситуаційні чинники (Saarni, 1993 : 435-446).

Отже, когнітивістські теорії дозволяють розглядати емоцію як емерджентний динамічний конструкт, який грунтується на оцінній діяльності, є ситуативно і соціально зорієнтованим. Вони витлумачують емоції через їх зв'язок 3 раціональною поведінкою людини, зокрема, пізнавальною діяльністю.

Комунікативні конщепції виходять із того, що діяльність опосередковує всі психічні процеси (Холод, 2011: 107) i наголошують на телеологічності емоцій, «функціонування яких підпорядковане цілі і зазвичай оцінюється у відповідності до неї: як позитивні, якщо мета досягнута, і негативні, якщо для цього існують перешкоди» (Oatley \& Johson-Laird, 1987).

У цілому, психологічні теорії емоцій уможливлюють виділити характерні ознаки емоцій, релевантні для лінгвістичного аналізу: емоції пов'язані з інстинктами, а розмаїття їх проявів і форм $\epsilon$ результатом еволюції; емоції нерозривно пов'язані з фізіологічними процесами, які відіграють вирішальну роль в процесі породження емоції та реакцій на неї; в основі емоційних процесів знаходиться мотивація як організуючий фактор свідомості; емоції є результатом оцінки ступеню задоволення потреб індивіда.

У психолінгвістичному дослідженні емоцій в кінодискурсі ми грунтуємось на даних психології i, визнаючи невід'ємний зв'язок 
мови 3 когнітивними процесами, зосереджуємо увагу на тому, ЯК (якими засобами) відбувається конструювання емоції колективним автором кінофільму i ЯКИМИ МОДУСАМИ смисл емоції передається аудиторії. Це дозволяє змоделювати процес породження емоційного смислу і проаналізувати механізм взаємозв'язку різних модусів у процесі трансляції смислу емоцій в кінодискурсі, що окреслює психолінгвістичний вектор дослідження. Психолінгвістика акцентує увагу на провідних характеристиках емоцій: (1) емоції $\epsilon$ «станом тіла» або «станом душі»; (2) їх основою $є$ потреби, мотиви, пізнавальні процеси; (3) емоції пов'язані з переробкою інформації; (4) емоційні процеси можуть відбуватись на свідомому i несвідомому рівнях; (5) емоції неоднакові, причому їх якісний i кількісний склад викликає суперечності (Мягкова, 2000: 10).

Базові емоції. Певні емоції визнаються базовими за різними критеріями: за параметром оцінки задоволення - незадоволення, прийняття - відштовхування виділено шість базових емоцій: любов, подив, страх, гнів, відраза, презирство (Нуркова \& Березанская, 2004). До основних ознак базових емоцій К. Ізард відносить такі характеристики: вони мають виразні й специфічні нервові субстрати; виявляють себе за допомогою виразної й специфічної конфігурації м'язових рухів (міміки); здійснюють організаційний вплив на людину, утворюючи мотиваційну систему людського існування (Izard, 1991: 63-64). Цим критеріям відповідають емоції страху та гніву, різноманітність форм їх прояву свідчить про їх вагомість для існування людської істоти. Відчуття страху може варіюватись від тривоги до жаху (Изард, 1980) і включати занепокоєння, переляк, страх, паніку, жах тощо (Ильин, 2001). Емоція гніву може проявлятись сильним незадоволенням, обуренням, люттю.

Подальший розподіл базових емоцій на позитивні й негативні виходить із їх полярності залежно від ступеню задоволення потреб індивіда (Рубинштейн, 1946) або успішності / неуспішності досягнення мети. Фрустраційна теорія Дж. Дьюї витлумачує виникнення негативних емоцій як реакцію на перешкоду, процес адаптації до нових умов (Dewey, 1895). Негативні емоції відіграють мобілізуючу роль, сприяють швидкому задоволенню потреб, що, у свою чергу, надає поштовх до виникнення позитивних емоцій (Анохин, 1984). Негативні емоції, як образно визначає С. Томкінс, слугують «аварійнимим сигналами», які вказують на порушення 
The Intersemiosis of Negative Emotions in the Cinematic Discourse...

балансу (Tomkins, 1980: 155). За параметром досягнення / недосягнення цілей (Oatley \& Johson-Laird, 1987) та соціальної відповіді на дії індивідуумів до базових негативних емоцій віднесено страх, гнів, сум і відразу (Campos, 1984).

Кінодискурс як середовище конструювання емоцій. Наше дослідження негативних емоцій страху та гніву виявляє ïx специфічну ознаку у кінодискурсі - посилення прагматичного впливу через естетизацію комунікації, яка притаманна цьому мультимодальному та полікодовому типу дискурсу. Полікодовість кінодискурсу фокусує увагу на комбінації декількох кодових систем - вербальної, невербальної і позалінгвальної (музика, шуми, свтіло, кадри, монтаж тощо), які залучені творцями кінофільму для конструювання смислу. Мультимодальний характер кінодискурсу акцентує його динамічну природу і відображає спрямованість на адресата з урахуванням когнітивних i соціальних факторів. За допомогою «інформаційних каналів» - візуального i аудіального модусів («акустичного», за Г. Крессом (Kress, Jewitt, Ogborn \& Tsatsarelis, 2014)), фільм транслює смисли, сконструйовані за допомогою комбінації семіотично гетерогенних кодів.

Реконструювання смислу глядачами відбувається на основі інференційного процесу умовиводу, який є соціальним і культурно закоріненим. Окремі модуси організовані у формі смислоутворюючих систем, в межах яких артикуляція смислів відбувається по-різному. За Г. Крессом, модуси є відкритими системами, що розвиваються i змінюються у відповідь на комунікативні потреби суспільства: нові модуси виникають, існуючі змінюються (Kress, Jewitt, Ogborn \& Tsatsarelis, 2014: 52). Різні модуси забезпечують різні виміри смислоутворення і вибір модуса конструює певний смисл. Модуси мають суб'єктивний характер: їх відбір залежить від індивіда (Kress, Jewitt, Ogborn \& Tsatsarelis, 2014: 202-203). У кінодискурсі модус $€$ активним творцем смислу, а не його пасивним носієм (Bateman \& Schmidt, 2012: 76). Як вказує Е. Тан, нарративний континуум фільму забезпечує вільне сприйняття та розуміння сюжету, дії, персонажів та їх внутрішнього життя. Емоційні реакції можна пояснити розвитком сюжету та розвитком психології героїв (Tan, 2018).

Емоціям у кінодискурсі притаманна інтерсуб'єктивність, яка зумовлює його здатність викликати адекватні емоції у глядача. Розглядаючи кінофільм як «машину емоцій», дослідники кіно 
стверджують, що в основі емоційності фільму лежать «теми» поведінкові сценарії емоцій, які відбивають спільний емоційний досвід творців фільму і глядачів (Grodal, 1999; Tan, 2014; Tan \& Frijda, 1999: 70). Створюючи образ і емоційний стан персонажів, творці фільму активують відповідні знання у свідомості глядачів, тобто збуджують їх афективну чуттєвість до певних культурних цінностей (Laine, 2007).

Людське тіло спілкується зі світом через емоції, тому невербаліка і кінокоди несуть комунікативну і суспільно-культурну інформацію, утілеснюючи емоційні смисли. Інтерсуб'єктивний простір тілесного досвіду колективного автора i аудиторії уможливлює конструювання емоції у кадрі та їх реконструкцію глядачем, а мова забезпечує «ключ», який повністю реалізує взаємозв'язок між утілесненою емоцією та людиною (Fusaroli, Demuru \& Borghi, 2012: 4). Фактично, слугуючи посередником між колективним автором і колективним реципієнтом, кінодискурс транслює емоційні смисли, реконструкція яких відбувається на основі універсального утілесненого підгрунтя емоційного досвіду людини: творці фільму співвідносять емоційний стан героїв 3 когнітивними скриптами емоцій у свідомості глядачів і активують ïx (Grodal, 1999: 75).

Дослідники спільні у думці, що кіноемоції мають асоціативний характер і залежать від сформованих у свідомості глядачів уявлень про певну емоцію та іiі прояви (Carroll, 1999; Plantinga, 1999; Smith, 2003). За допомогою кінозасобів фільм передає певні «сигнали», які відображають його емоційне навантаження. Гнучка мережа емоцій дозволяє творцям фільму створювати різноманітність асоціацій (сірий дощовий день, насуплені брова тощо), які сигналізують про певні емоції. Зокрема, музика тісно пов'язана 3 емоцією і виконує у фільмі прагматичні функції: передача емоцій героїв і настрою фільму та забезпечення комунікації з глядачами. Музичний супровід може підсилювати або послаблювати емоцію, що зумовлюється процесами емоційної узгодженості або поляризації (Smith, 1999: 167). Так, музичний код у фільмі «Fracture» здебільш викликає негативні емоції страху і гніву. Впливовість цього супроводу пояснюється тим, що канадський композитор Джефф Данна спеціалізується на музиці до фільмів жахів і трилерів. Наприклад, у кадрі, що передує вбивству Теодором Кроуфордом 
The Intersemiosis of Negative Emotions in the Cinematic Discourse...

своєї дружини, під час розмови подружжя, звучить музичний супровід, якому характерне використання різких, «нелінійних», немилозвучних звуків, які не тільки створюють емоційний стан страху, але й збільшують емоційний вплив мізансцени. Дженніфер Кроуфорд боїться, що чоловікові стане відомо про іiі подружню зраду, вона налякана майбутнім викриттям, що реалізовано в мізансцені невербальними засобами i екстралінгвально - за допомогою музики, яка підсилює відчуття страху. Ї̈ї страх посилюється, коли вона усвідомлює намір чоловіка:

(1) Crawford I know. Everything.

\#She stops, exhales. Looking down. Afraid. Grateful it's happening at last\#.

@Крупний план Дженіфер. Музичний супровіднаростає.@

Jennifer I'm so sorry.

Crawford Don't be. Knowledge is pain. I'm used to that. @ Крупний план Кроуфорда. Музичний супровід. @

\#Jennifer winces, feeling some sympathy. Preparing herself to turn and end it, to grow, to move on\#.@ Крупний план Дженіфер. музичний супровід.@

Crawford It's not like I don't let little pleasures, in return for the pain.

\#She frowns and turns - and her eyes go big with fear\#. @ музичнийсуnровід@

\#Crawford is holding a semi-automatic pistol, aimed at her face. Very still.\# (Fracture)

На відміну від «Fracture» музика «Titanic», створена Дж.Р. Хорнером, відрізняється ліричністю та використанням кельтских мотивів. Разом із нелінгвальним кодом - просодичними засобами (крики про допомогу) i кінетичними засобами (переляканий вираз обличчя), вона слугує ситуативним засобом конструювання емоції страху в епізоді, коли пасажири Титаніка усвідомили свою неминучу загибель і в паніці метушаться на борту корабля, намагаючись знайти порятунок:

(2) The propellers are 100 feet out of the water and rising. Panicking people leap from the poop deck rail, fall screaming and hit the water like mortar rounds. A man falls from the poop deck, hitting the bronze hub of the starboard propeller with a sickening smack. (Titanic) 
Інтерсеміозис негативних емоцій у кінодискурсі: психолінгвістичний...

В основі прагматичного впливу кіноемоцій на глядачів лежить «ідентифікація» - здатність глядачів ідентифікувати себе 3 героями фільму, що сприяє виникненню у них емпатії (Gaut, 1999; Tan, 2018). Ідентифікуючи себе $з$ кіногероями, глядачі відчувають ті самі емоції і переживають їх. Досягненню цього ефекту сприяє використання окремих каналів: зокрема, емоційні асоціації передаються різними модальностями кінодискурсу: за допомогою виразу обличчя, руху, голосу і тону, костюмів акторів, звуку, музики, освітлення, мізансцени, декорацій, камери, монтажу, глибини знімальної площадки тощо (Smith, 2003: 42). На думку Б. Гаут, значна роль належить зйомці суб'єктивною камерою, яка фіксує «точку перцептивної ідентифікації», коли глядач бачить і переживає те саме, що і герой (Gaut, 1999: 208). До основних засобів передачі емоцій відносять зображення обличчя людини, тож крупний план обличчя займає центральне місце в передачі кіноемоцій, відсилаючи нас назад в долінгвістичну комунікацію (Plantinga, 1999: 239), як наприклад, в епізоді фільму «Тіtanic», коли Рут, матір Рози, намагається переконати іï вийти заміж за промисловця Кела Гоклі для покращення скрутного фінансового становища сім’ї. Вона боїться відмови Рози вийти заміж, що призведе їі до бідності:

(3) Ruth I don't understand you. It is a fine match with Hockley, and it will insure our survival.

Rose \#hurt and lost\# How can you put this on my shoulders?

Rose \#turns to her, and we see what Rose sees@крупний план@, @зйомка суб'єктивною камерою@ - the naked fear in her mother's eyes\#.

Ruth Do you want to see me working as a seamstress? Is that what you want? Do you want to see our fine things sold at an auction, our memories scattered to the winds? My God, Rose, how can you be so selfish? (Titanic)

Успішність емоційного впливу на глядача залежить від емоційної узгодженості між контекстом кінооповідання, характерами кіногероїв і різними кінозасобами. Як стверджує К. Плантінга, фільм є гібридним мистецтвом, яке змішує композиційні елементи колір, звуки разом з рухом, ритмом задля реалістичного відтворення світу (Plantinga, 1999: 253-254). До прикладу, візуальний модус у фільмі «Titanic» конструює емоцію страху під час катастрофи. Перелякані обличчя людей, їх різкі, хаотичні спроби попасти на 
The Intersemiosis of Negative Emotions in the Cinematic Discourse...

рятівну шлюпку, зображення руйнування корабля, світло від ракети сигналу про допомогу, переривчасте світло від згасаючої ілюмінації лайнера, що супроводжує синкопована музика, утворюють картину загальної паніки:

(4) \#Second officer lightoller is loading the boat nearest Cal and Rose..Boat 6\#.

Lightoller Women and children only! Sorry sir, no men yet.

\#Another rocket bursts overhead, lighting the crowd. Startled faces turn upward. Fear now in the eyes\#. (Titanic)

Кінозасоби, залучені для формування емоцій, підпорядковуються певним стратегіям і тактикам, які вибирають творці кінофільму, базуючись на власному емоційному досвіді. Так, для передачі страху використовують тактику шоку в фільмах жахів. За нашими даними, для конструювання негативних емоцій у кінодискурсі, колективний автор обирає паритетне / непаритетне використання окремих кодів. У першому випадку гетерогенні семіотичні коди рівною мірою слугують означуванню страху, у другому перевагу віддано одному з кодів - лінгвальному, нелінгвальному, позалінгвальному, що зумовлює домінування відповідних модусів - аудіального або візуального. Серед непаритетних стратегій конструювання емоційних смислів зафіксовано превалювання певних кодів:

а. лінгвальних засобів конструювання емоцій:

У фрагменті фільму «Fracture» в мізансцені святкового обіду сім’ї відбувається розмова між Ніккі Гарднер і Віллі Бічам. Ніккі сподівається, що Віллі залишив справу Теда Кроуфорда, яка могла зіпсувати кар'єру Віллі та Ніккі. Проте, коли виявилось, що Віллі вирішив продовжувати працювати над нею, вона відчуває гнів. У наступному епізоді емоція реалізована лексичною одиницею із семою негативної оцінки stupid, яка критично оцінюе розумові здібності об'єкта; вона інтенсифікована прислівником really, та синтаксично - за допомогою сегментованого риторичного питання.

WILLY I asked him not to.

\#Silence. Nikki is staring at him. Angry\#.

NIKKI You are really stupid, did you know that?

\#Willy doesn't know how to handle this; everyone else tries to be polite, eating and pretending not to notice\#. (Fracture) 
б. нелінгвальні засоби конструювання емоцій: (мімічні, кінесичні, просодичні, проксемічні), як в епізоді з фільму «Titanic», коли Роза і Джек чують плач переляканого хлопчика і знаходять його одного в крижаній воді. Емоційний стан дитини сконструйовано просодично (пронизливий крик) і мімічно (перелякане обличчя):

Then they hear it... a CRYING CHILD. Below them. They go down a few steps to looks along the next deck.

The corridor is awash, about a foot deep. Standing against the wall, about 50 feet away, is a little BOY, about 3. The water swirls around his legs and he is wailing. (Titanic)

в. аудіо / відеокоди конструювання емоцій:

Панічний страх, який відчувають пасажири Титаніка, що тоне, утілено за допомогою відеоряду (люд, які метушаться на палубі, поступове руйнування корабля) i аудіального коду (загальний шум), який складається 3 криків людей, звуків руйнування i фонової музики:

\#Jack and Rose run out of the PALM COURT into a dense crowd. Jack pushes his way to the rail and looks at the state of the ship. The bridge is under water and there is chaos on deck. Jack helps her put her lifebelt on. People stream around them, shouting and pushing\#.

Jack Okay... we keep moving aft. We have to stay on the ship as long as possible.

\#They push their way aft through the panicking crowd\#. (Titanic)

У свою чергу, поєднання гетерогенних семіотичних засобів конструювання емоцій у кінодискурсі здійснюється у конгруентний або неконгруентний спосіб. За умови конгруентності, різні коди одночасно актуалізують однакові емотивні значення; неконгруентність інтерсеміозису емоцій полягає в тому, що гетерогенні семіотичні засоби одночасно актуалізують різні емотивні смисли, що надає додаткової експресивності таким емоціям i підвищує ефективність їх впливу на глядача. Наприклад, в епізоді, коли після врятування Рози від самогубства, Джек був змушений збрехати іiі нареченому про нещасний випадок, омовлені емоційні смисли у діалозі персонажів Лавджоя, слуги Кела Гоклі, і Джека, протирічать візуальному нелінгвальному коду:

LOVEJOY You'll want to tie those.

\#(Jack looks at his shoes)\# 
The Intersemiosis of Negative Emotions in the Cinematic Discourse...

Interesting that the young lady slipped so mighty all of a sudden and you still had time to take off your jacket and shoes. Mmmm? \#Lovejoy's expression is bland, but the eyes are cold. He turns away to join his group.\#

Візуальний нелінгвальний код, реалізований мімічно незадоволеним, «холодним» поглядом, свідчить, що Лавджой відчуває негативну емоцію гніву, що суперечить його вербальній поведінці.

\section{Висновки}

Проведене дослідження виявляє психологічні та психолінгвістичні засади інтерсеміозису негативних емоцій одночасного мультимодального конструювання емотивних значень у полікодовому англомовному художньому кінодискурсі. До важливіших психологічних ознак емоцій, релевантних для лінгвістичного аналізу, належать: їх еволюційно-біологічна природа; нерозривний зв'язок з фізіологічними процесами; закоріненість у спільному утілесненому досвіді індивідів; в основі емоційних процесів знаходиться мотивація, яка не тільки впливає на когнітивну сферу і поведінку людини, але й виступає організуючим фактором свідомості; емоції $є$ результатом оцінки ступеню задоволення потреб індивіда.

Психолінгвістичний аспект породження емотивного смислу в кінодискурсі реалізовано виявленням моделей інтерсеміозису емоцій через взаємодію гетерогенних полікодових засобів - лінгвальних, нелінгвальних (просодика, кінесика тощо) i позалінгвальних (музичні та кінокоди), актуалізованою різними модальностями аудіальною та візуальною. Конструювання емотивних смислів у кінодискурсі $\epsilon$ результатом інтеракції між реальним світом творців фільму і уявним світом дієгезісу. Специфіка негативних кіноемоцій, зокрема страху та гніву, полягає у їх високій експресивності, зумовленій естетикою кіно.

Моделі конструювання негативно-емотивних значень творцями кінодискурсу включають як семіотично-кодову паритетність, так i непаритетність (домінування одного 3 кодів). У першому випадку гетерогенні семіотичні коди рівною мірою слугують означуванню 
Інтерсеміозис негативних емоцій у кінодискурсі: психолінгвістичний...

страху чи гніву, у другому перевагу віддано одному 3 кодів лінгвальному, нелінгвальному або позалінгвальному. Відповідно, це зумовлює домінування одного 3 модусів - аудіального або візуального.

За параметром узгодженості емотивних значень страху і гніву, утілюваних різнокодовими засобами інтерсеміозису, окремі епізоди англомовного художнього кінодискурсу $\epsilon$ конгруентними або неконгруентними. За умови конгруентності, лінгвальні, нелінгвальні, музично-шумові та кінокоди одночасно актуалізують однакові емотивні значення; неконгруентність гетерогенних семіотичних засобів полягає в актуалізації ними різних емотивних смислів, що зумовлює підвищену експресивність таких емоцій i ефективність їх впливу на глядача.

До перспектив дослідження інтерсеміозису негативних емоцій в кінодискурсі належить визначення характеристик конструювання інших базових негативних емоцій як в англомовному, так i в іншомовних кінодискурсах.

\section{Література}

Анохин П.К. Эмоции. Психология эмоций. Москва: Изд-во Моск. ун-та, 1984. С. 180-205.

Бреслав Г.М. Психология эмоций. Москва: Смысл, Академия. 2004. 544 с.

Вилюнас В.К. Психология эмоциональных явлений. Москва: Изд-во МГУ, 1976. 143 c.

Джемс У. Психология. Москва: Педагогика, 1991. 368 с.

Ельмслев Л. Пролегомены к теории языка. Москва: КомКнига, 2006. 248 с.

Засєкіна Л.В. Тенденції розвитку вітчизняної психолінгвістики: методологічний огляд проблем та окреслення шляхів їх вирішення. Психолінгвістика. 2008. Вип. 1. С. 9-20.

Изард К.Э. Эмоции человека. Москва: Изд-во Московского ун-та, 1980. 440 с.

Ильин Е.П. Эмоции и чувства. Санкт Петербург: Питер, 2001. 752 с.

Ланге Г. Душевные движения. Психология эмоций. Москва, Санкт Петербург: Питер, 2004. С. 112-130.

Леонтьев А.Н. Потребности, мотивы и эмоции. Москва: МГУ, 1971. 40 с.

Мягкова О.Ю. Эмоционально-чувственный компонент значения слова: автореф. дисс. ... д. филол. наук : 10.02.19. Москва, 2000. 43 с.

Нуркова В.В., Березанская Н.Б. Психология. Москва: Юрайт-Издат, 2004. 484 с.

Психологическая энциклопедия / Под ред. Р. Корсини, А. Ауэрбаха. 2-е изд. Санкт Петербург: Питер, 2006. 1096 с.

Рубинштейн С.Л. Основы общей психологии. Москва: Учпедгиз, 1946. 460 с. Фестингер Л. Теория когнитивного диссонанса. Москва: Эксмо, 2018. 256 с.

Холод О.М. Комунікаційні технології. Київ: КиМУ, 2011. 312 с. 
The Intersemiosis of Negative Emotions in the Cinematic Discourse...

Экман П. Психология эмоций. Я знаю, что ты чувствуешь. Санкт Петербург: Питер, 2010. 334 с.

Argaman, O. (2010). Linguistic markers and emotional intensity. Journal of Psycholinguistic Research, 39(2), 89-99. https://doi.org/10.1007/s10936-009-9127-1

Arnold, M.B. (1970). Feelings and emotions. New York: Columbia University Press.

Bamberg, M. (1997). Language, Concepts and Emotions: the Role of Language in the Construction of Emotions. Language Sciences, 19(4), 309-340. https://doi. org/10.1016/S0388-0001(97)00004-1

Bateman, J.A., \& Schmidt, K.H. (2012). Multimodal Film Analysis. How Films Mean. London, New York: Routledge.

Campos, J., \& Barrett, K. (1984). Towards a new understanding of emotions and their development. In C. Izard, Kagan \& R. Zajonc (Eds.), Emotions, Cognition and Behavior (pp. 229-263). New York: Cambridge University Press.

Carroll, N. (1999). Film, Emotion, and Genre. In C. Platinga \& G.M. Smith (Eds.), Passionate View: Film, Cognition and Emotion (pp. 21-47). Baltimore, London: The Johns Hopkins University Press.

Dewey, J. (1895). The Theory of Emotion. The Significance of Emotionsю Psychological Review 2, 13-32. https://doi.org/10.1037/h0070927

Fracture. (n.d.). Retrieved from http://www.imsdb.com/scripts/Fracture.html

Frijda, N.H. (1986). The Emotions (Studies in Emotion and Social Interaction). Cambridge: Cambridge University Press.

Fusaroli, R., Demuru, P., \& Borghi, A.M. (2012) The Intersubjectivity of Embodiment. Journal of Cognitive Semiotics, 4(1), 1-5.

Gaut, B. (1999). Identification and Emotion in Narrative Film. In C. Platinga \& G.M. Smith (Eds.), Passionate View: Film, Cognition and Emotion (pp. 200216). Baltimore, London : The Johns Hopkins University Press.

Grodal, T. (1999). Emotions, Cognitions, and Narrative Patterns in Film. In C. Platinga \& G.M. Smith (Eds.), Passionate View: Film, Cognition and Emotion (pp. 127-145). Baltimore, London: The Johns Hopkins University Press.

Izard, C.E. (1991). The Psychology of Emotions. New York: Plenum. https://doi. org/10.1007/978-1-4899-0615-1

Kress, G., Jewitt, C., Ogborn, J., \& Tsatsarelis, C. (2014). Multimodal Teaching and Learning. The Rhetorics of the Science Classroom. London: Bloomsbury.

Laine, T. (2007). Shame and Desire: Emotion, Intersubjectivity, Cinema. Brussels: Peter Lang.

Oatley, K., \& Johson-Laird, P. (1987). Towards a cognitive theory of emotions. Cognition and Emotion, 1, 29-50. https://doi.org/10.1080/02699938708408362

Plantinga, C. (1999). The Scene of Empathy and the Human Face on Film. In C. Platinga \& G.M. Smith (Eds.), Passionate View: Film, Cognition and Emotion (pp. 239-255). Baltimore, London: The Johns Hopkins University Press.

Saarni, C. (1993). Socialization of emotion. In M. Lewis \& J.M. Haviland (Eds.), Handbook of Emotions (pp. 435-446). New York, London: Guilford Press.

Smith, G.M. (2003). Film Structure and the Emotion System. Cambridge: Cambridge University Press. https://doi.org/10.1017/CBO9780511497759

Smith, J. (1999). Movie Music as Moving Music: Emotion, Cognition, and the Film Score. In C. Platinga \& G.M. Smith (Eds.), Passionate View: Film, Cognition and Emotion (pp. 146-167). Baltimore, London: The Johns Hopkins University Press.

Strongman, K.T. (2003). The Psychology of Emotion. Chichester: Wiley.

Tan, E.S. (2018). A Psychology of the Film. Palgrave Communications, 4(1), 82. https://doi.org/10.1057/s41599-018-0111-y 
Інтерсеміозис негативних емоцій у кінодискурсі: психолінгвістичний...

Tan, E.S. (2014). Engaged and Detached Film Viewing: Exploring Film Viewers' Emotional Action Readiness. In T. Nannicelli \& P. Taberham (Eds.), Cognitive Media Theory (pp. 106-123). New York, NY: Routledge.

Tan, E.S., \& Frijda, N.H. (1999). Sentiment in Film Viewing. In C. Platinga \& G.M. Smith (Eds.), Passionate View: Film, Cognition and Emotion (pp. 48-64). Baltimore, London: The Johns Hopkins University Press.

Titanic. (n.d.). Retrieved from https:/www.imsdb.com/scripts/Titanic.html

Tomkins, S.S. (1980). Affect as amplification: Some modifications in theory. In R. Plutchik \& H. Kellerman (Eds.), Emotion: Theory, Research, and Experience (Vols. 1), (pp. 153-159). New York: Academic Press.

\section{References}

Anohin, P.K. (1984). Emotsii [Emotions]. Psihologiya emotsiy - Psychology of emotions (pp. 180-205). Moscow : Izd-vo Mosk. un-ta. [in Russian].

Breslav, G.M. (2004). Psihologiya emotsiy [Psychology of emotions]. Moscow: Smysl, Akademiya [in Russian].

Vilyunas, V.K. (1976). Psihologiya emotsionalnyih yavleniy [Psychology of emotional phenomena]. Moscow: Izd-vo MGU [in Russian].

Dzhems, U. (1991). Psihologiya [Psychology]. Moscow: Pedagogika [in Russian].

Elmslev, L. (2006). Prolegomenyi $k$ teorii yazyika [Prolegomena to the theory of language]. Moscow: KomKniga [in Russian].

Zasiekina, L.V. (2008). Tendentsii rozvytku vitchyznianoi psykholinhvistyky: metodolohichnyi ohliad problem ta okreslennia shliakhiv yikh vyrishennia [Trends in the development of domestic psycholinguistics: a methodological review of problems and ways to solve them]. Psykholinhvistyka - Psycholinguistics, 1, 9-20 [in Ukrainian]

Izard, C.E. (1980). Emotsii cheloveka [Human emotions]. Moscow: Izd-vo Moskovskogo un-ta [in Russian].

Ilin, E.P. (2001). Emotsii $i$ chuvstva [Emotions and feelings]. Saint Petersburg: Piter [in Russian].

Lange, G. (2004). Dushevnyie dvizheniya [Mental movements]. Psihologiya emotsiy Psychology of emotions (pp. 112-130). Moscow, Saint Petersburg: Piter [in Russian].

Leontev, A.N. (1971). Potrebnosti, motivyi i emotsii [Needs, motives and emotions]. Moscow: MGU [in Russian].

Myagkova, O.Yu. (2000). Emotsionalno-chuvstvennyiy komponent znacheniya slova [Emotional-sensual component of the meaning of the word]. Extended abstract of candidate's thesis. Moscow [in Russian].

Nurkova, V.V., \& Berezanskaya, N.B. (2004). Psihologiya [Psychology]. Moscow: Yurayt-Izdat [in Russian].

Korsini, R., \& Auerbakha, A. (Ed.). (2006). Psihologicheskaya entsiklopediya [Psychological Encyclopedia] (2th ed.). Saint Petersburg: Piter [in Russian].

Rubinshteyn, S.L. (1946). Osnovyi obschey psihologii [Basics of General Psychology]. Moscow: Uchpedgiz [in Russian].

Festinger, L. (2018). Teoriya kognitivnogo dissonansa [Theory of cognitive dissonance]. Moscow: Eksmo. [in Russian]. 
The Intersemiosis of Negative Emotions in the Cinematic Discourse...

Kholod, O.M. (2011). Komunikatsiini tekhnolohii [Communicative technologies]. Kyiv: KyMU [in Ukrainian].

Ekman, P. (2010). Psihologiya emotsiy. Ya znayu, chto tyi chuvstvuesh [Psychology of emotions. I know what you feel]. Saint Petersburg: Piter [in Russian].

Argaman, O. (2010). Linguistic markers and emotional intensity. Journal of Psycholinguistic Research, 39(2), 89-99. https://doi.org/10.1007/s10936-009-9127-1

Arnold, M.B. (1970). Feelings and emotions. New York: Columbia University Press.

Bamberg, M. (1997). Language, Concepts and Emotions: the Role of Language in the Construction of Emotions. Language Sciences, 19(4), 309-340. https://doi. org/10.1016/S0388-0001(97)00004-1

Bateman, J.A., \& Schmidt, K.H. (2012). Multimodal Film Analysis. How Films Mean. London, New York: Routledge.

Campos, J., \& Barrett, K. (1984). Towards a new understanding of emotions and their development. In C. Izard, Kagan \& R. Zajonc (Eds.), Emotions, Cognition and Behavior (pp. 229-263). New York: Cambridge University Press.

Carroll, N. (1999). Film, Emotion, and Genre. In C. Platinga \& G.M. Smith (Eds.), Passionate View: Film, Cognition and Emotion (pp. 21-47). Baltimore, London: The Johns Hopkins University Press.

Dewey, J. (1895). The Theory of Emotion. The Significance of Emotionsю Psychological Review 2, 13-32. https://doi.org/10.1037/h0070927

Fracture. (n.d.). Retrieved from http://www.imsdb.com/scripts/Fracture.html

Frijda, N.H. (1986). The Emotions (Studies in Emotion and Social Interaction). Cambridge: Cambridge University Press.

Fusaroli, R., Demuru, P., \& Borghi, A.M. (2012) The Intersubjectivity of Embodiment. Journal of Cognitive Semiotics, 4(1), 1-5.

Gaut, B. (1999). Identification and Emotion in Narrative Film. In C. Platinga \& G.M. Smith (Eds.), Passionate View: Film, Cognition and Emotion (pp. 200216). Baltimore, London : The Johns Hopkins University Press.

Grodal, T. (1999). Emotions, Cognitions, and Narrative Patterns in Film. In C. Platinga \& G.M. Smith (Eds.), Passionate View: Film, Cognition and Emotion (pp. 127-145). Baltimore, London: The Johns Hopkins University Press.

Izard, C.E. (1991). The Psychology of Emotions. New York: Plenum. https://doi. org/10.1007/978-1-4899-0615-1

Kress, G., Jewitt, C., Ogborn, J., \& Tsatsarelis, C. (2014). Multimodal Teaching and Learning. The Rhetorics of the Science Classroom. London: Bloomsbury.

Laine, T. (2007). Shame and Desire: Emotion, Intersubjectivity, Cinema. Brussels: Peter Lang.

Oatley, K., \& Johson-Laird, P. (1987). Towards a cognitive theory of emotions. Cognition and Emotion, 1, 29-50. https://doi.org/10.1080/02699938708408362

Plantinga, C. (1999). The Scene of Empathy and the Human Face on Film. In C. Platinga \& G.M. Smith (Eds.), Passionate View: Film, Cognition and Emotion (pp. 239-255). Baltimore, London: The Johns Hopkins University Press.

Saarni, C. (1993). Socialization of emotion. In M. Lewis \& J.M. Haviland (Eds.), Handbook of Emotions (pp. 435-446). New York, London: Guilford Press.

Smith, G.M. (2003). Film Structure and the Emotion System. Cambridge: Cambridge University Press. https://doi.org/10.1017/CBO9780511497759

Smith, J. (1999). Movie Music as Moving Music: Emotion, Cognition, and the Film Score. In C. Platinga \& G.M. Smith (Eds.), Passionate View: Film, Cognition and Emotion (pp. 146-167). Baltimore, London: The Johns Hopkins University Press. 
Інтерсеміозис негативних емоцій у кінодискурсі: психолінгвістичний...

Strongman, K.T. (2003). The Psychology of Emotion. Chichester: Wiley.

Tan, E.S. (2018). A Psychology of the Film. Palgrave Communications, 4(1), 82. https://doi.org/10.1057/s41599-018-0111-y

Tan, E.S. (2014). Engaged and Detached Film Viewing: Exploring Film Viewers' Emotional Action Readiness. In T. Nannicelli \& P. Taberham (Eds.), Cognitive Media Theory (pp. 106-123). New York, NY: Routledge.

Tan, E.S., \& Frijda, N.H. (1999). Sentiment in Film Viewing. In C. Platinga \& G.M. Smith (Eds.), Passionate View: Film, Cognition and Emotion (pp. 48-64). Baltimore, London: The Johns Hopkins University Press.

Titanic. (n.d.). Retrieved from https:/www.imsdb.com/scripts/Titanic.html

Tomkins, S.S. (1980). Affect as amplification: Some modifications in theory. In R. Plutchik \& H. Kellerman (Eds.), Emotion: Theory, Research, and Experience (Vols. 1), (pp. 153-159). New York: Academic Press.

\section{АНОТАЦІЯ}

Дослідження психолінгвістичних властивостей негативних емоцій в англомовному художньому кінодискурсі присвячене встановленню їх інтерсеміозису - одночасному мультимодальному конструюванню емотивних значень засобами гетерогенних полікодових систем. До полікодових засобів конструювання значень кінодискурсу відносимо лінгвальні, нелінгвальні (просодика, кінесика тощо) і позалінгвальні (музичні та кінокоди), до різних модусів - аудіальні та візуальні канали актуалізації смислів. Важливішими лінгвопсихологічними ознаками кіноемоцій виявляються їх нерозривний зв'язок з фрізіологічними процесами, закоріненість у спільному утілесненому досвіді індивідів, мотиваційна основа; емоції є результатом оцінки ступеню задоволення потреб індивіда. Конструювання емотивних смислів у кінодискурсі $\epsilon$ результатом інтеракції між реальним світом творців фольму і уявним світом дієгезісу. У конструюванні негативних емотивних значень, у цілому, $і$ емоцій страху та гніву, зокрема, колективний автор кінодискурсу використовує разні коди як паритетно, так і непаритетно. У першому випадку гетерогенні семіотичні коди рівною мірою слугують означуванню страху, у другому перевагу віддано одному з кодів - лінгвальному, нелінгвальному або позалінгвальному. Відповідно, це зумовлює домінування одного з модусів транслювання смислів колективному глядачу - аудіального або візуального. За параметром узгодженості емотивних значень страху і гніву, утілюваних різнокодовими засобами семіозису, окремі епізоди англомовного художнього кінодискурсу $\epsilon$ конгруентними або неконгруентними. За умови конгруентності, різні коди одночасно актуалізують однакові емотивні значення; неконгруентність гетерогенних семіотичних засобів полягає в актуалізацї різних емотивних смислів, що зумовлює підвищену експресивність таких емоцій і ефективність їх впливу на глядача.

Ключові слова: інтерсеміозис, кінодискурс, конструювання емотивних значень, негативні кіноемочії, полікодові засоби, мульмимодальність. 
The Intersemiosis of Negative Emotions in the Cinematic Discourse...

Крысанова Татьяна, Шевченко Ирина. Интерсемиозис негативных эмоций в кинодискурсе: психолингвистический ракурс

\begin{abstract}
АННОТАЦИЯ
Исследование психолингвистических свойств негативных эмоций в англоязычном художественном кинодискурсе посвящено определению их интерсемиозиса - одновременного мультимодального конструирования эмотивных значений средствами гетерогенных поликодовых систем. К поликодовым средствам конструирования значений кинодискурса относим лингвистические, нелингвистические (просодика, кинесика т.д.) и внелингвистические (музыкальные и кинокоды), а к различным модусам аудиальные и визуальные каналы актуализации смыслов. Важнейшими лингвопсихологическими признаками киноэмоций служат их неразрывная связь с физиологическими процессами, укорененность в общем отелесненном опыте индивидов, мотивационная основа; эмоции являются результатом оценки степени удовлетворения потребностей индивида. Конструирование эмотивных смыслов в кинодискурсе является результатом взаимодействия между реальным миром создателей фильма и воображаемым миром диегезиса. В конструировании негативных эмотивных значений, в челом, и эмоции страха и гнева, в частности, коллективный автор кинодискурса использует разнородные коды как паритетно, так и непаритетно. В первом случае гетерогенные семиотические коды в равной степени служат означиванию страха или гнева, во втором предпочтение отдано одному из различных кодов - лингвистическому, нелингвистическому, внелингвистическому. Соответственно, это приводит к доминированию одного из модусов трансляции смыслов коллективному зрителю - аудиальному или визуальному. По параметру согласованности эмотивных значений страха и гнева, воплощенных разнокодовыми средствами семиозиса, отдельные эпизоды англоязычного художественного кинодискурсу является конгруэнтными или неконгруэнтными. При конгруэнтности различные коды одновременно актуализируют одинаковые эмотивные значения; неконгруэнтность гетерогенных семиотических средств заключается в актуализаций различных эмотивных смыслов, что приводит к повышенной экспрессивности таких эмоций и эффективности их воздействия на зрителя.
\end{abstract}

Ключевые слова: интерсемиозис, кинодискурс, конструирование эмотивных значений, негативные киноэмоции, поликодовые средства, мульмимодальность. 